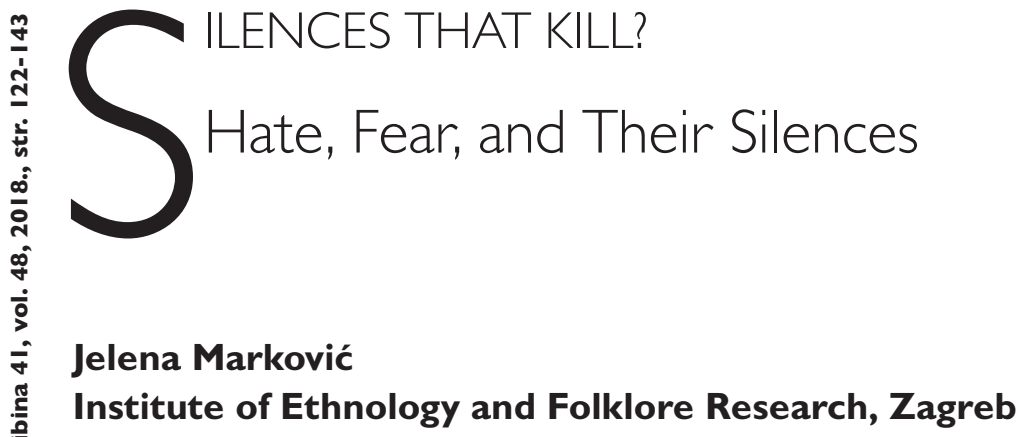

\begin{abstract}
This paper focuses on providing answers to three basic research questions on the basis of political discourse in Croatia (which produces fear through the use of explicit and implicit speech of exclusion and often also hate speech) and research into marginalized groups' personal narratives of fear and anxiety. First, how is hate narratively shaped in public discourse and personal narratives? Second, how does the language of hate affect those who are designated as objects of hate? Third, can and to what degree do the subjects of anxiety/fear (i.e. the explicit object of hate) narrate their experience and emotional response to hate? The author is interested in the places in which hate (which is itself marked by silence) generates fear and silence, the places in which hate erodes the subjects' need for intersubjectivity and leads to a deep sense of isolation and being silent, and which also sometimes leads to articulated resistance.
\end{abstract}

Keywords: language of hate, hate speech, fear, silence, empathy, gossips, personal narrative, conspiracy theory, affective atmosphere, affective politics

I imagine one of the reasons people cling to their hates so stubbornly is because they sense once hate is gone, they will be forced to deal with pain.

James Baldwin

An emotion such as fear is a way of being present in the world. On the other hand, a world you fear is a place where you can never feel completely at home.

Lars Svendsen

\title{
Introduction'
}

In Croatia, hate speech and the language of hate and exclusion are an everyday phenomenon in all three agoras, or verbal marketplaces, as identified and described by John Miles Foley (2012): the oral, the print or textual, and the electronic. The three are mutually related, and most appear as mirror images of each other (Foley 2012: 40-41). By relying on Foley's concept of the agoras, the material which served as the basis for the following deliberations was obtained from the respective domains of all three agoras.

${ }^{1}$ This article has been financed by the Croatian Science Foundation ("Narrating Fear: From Old Records to New Orality", Project No. IP-06-2016-2463). 
This study is based on material obtained from media, social networks, and websites $^{2}$ over the last three years, ${ }^{3}$ as well as on material obtained through fieldwork focused on personal narratives used to give shape to experiences of fear and anxiety, dehumanization, and discrimination during the war and post-war periods in Croatia. The fieldwork was conducted in 2012 in two Croatian cities which were not directly affected by the war in the 1990s (in the capital, Zagreb, at the Rehabilitation Centre for Stress and Trauma; and in Pula, a multicultural city that housed the largest naval base until the breakup of Yugoslavia). The fieldwork in Pula was continued twice in 2017 and then again in 2018, along with a repeated inquiry in 2017 in Lika, the Croatian region located right on the front line during the war. ${ }^{4}$ What the interlocutors from all three locations have in common is their participation in the affective atmosphere in Croatia, in which they, as members of an undesirable group, are often the targets of hate speech, regardless of their differing experiences of the war (all interlocutors were civilians during the war) and differing social status. As they shape their affective responses to such an atmosphere, they generally employ similar narrative strategies in the context of different personal narratives.

I would like to state in the introduction that it is my epistemological, political, and personal decision not to list examples of hate speech in this text, because I believe that its inscription would only serve to further empower and disseminate it, or could, at the very least, lead to unexpected, uncontrollable, and potentially harmful

\footnotetext{
${ }^{2}$ I checked the following websites: www.index.hr, www.jutarnji.hr, www.vecernji.hr. I collected statuses and comments posted on Facebook, which I mostly happened to run into during my personal use of the service. I took partial notes of statements made by public figures on TV.

${ }^{3}$ Numerous social stakeholders and public figures have warned of the growing intolerance towards minorities and those holding dissenting opinions (artists, journalists, scientists) in the past three years, along with the normalisation of historical revisionism and similar trends. The recent occurrences in Croatia are not just the legacy of the past war. The increased frequency of hate speech is connected to the current interests of particular groups. To illustrate this point, I would like to refer readers to an art project called “The Register of Traitors" (http://www.registarizdajnika.org/, accessed 5. 10.2018), which was created as a response to an early 2016 initiative from a minister in the Croatian government, in which the minister announced that "a register of traitors to the national interests of the Republic of Croatia and aggressors against the Republic of Croatia” was to be published. People were invited to include themselves in the register. In a humorous manner and from an ironic distance, the project identifies the groups which have become the targets of intolerance.

${ }^{4}$ One could justifiably raise the question of why the research was "stretched out" over a relatively long period of time. Firstly, the study of hate speech and exclusion was not initially the only nor the primary research goal. The subject emerged as a relevant one from material initially obtained during a study of experiences of war and the post-war period (especially among children) and the process of dehumanisation (2012), and later as part of the "Narrating Fear" project. The primary goal of the project was to examine narrative strategies and narrated/narrative events in which fears are formed, encouraged, directed, and dissolved in everyday direct communication, as well as in public discourse, in the media, and on social networks (2017 and 2018). Secondly, fieldwork with people who are traumatised or disenfranchised is marked by numerous obstacles, a lack of trust, fear, and various decisions made by both the researcher and the subjects of the research, all of which hinder the research process, the cognitive process, and the process of writing. In all locations mentioned previously, some interviews were not recorded, mostly because the interlocutors objected to it, but also because there were situations in which I assumed that awareness of the conversation being recorded would jeopardise the cohesion and unrepeatability of the intense communication taking place, which, from a folklorist perspective, which sees the text in context differently than ethnology and cultural anthropology (cf. Lozica 1979: 46), became a methodological and epistemological question, rather than just a question of interpersonal relations. Some interlocutors subsequently expressed doubts about their decision to allow the conversations to be recorded (despite their initial consent). In summary, this is a very sensitive research process, which leads to a whole series of rather uncomfortable epistemological, political, personal, and other decisions.
} 
consequences, which is a risk I am not prepared to take, personally or professionally. The basic mechanism of the fear being researched, and which is thus embedded in this text - one which seeps into one's personal world from the public sphere and vice-versa - can be observed within this decision itself. The result of this mechanism is that drawing attention to the recent fears of one's own community also means that one inevitably has to "veer", both personally and professionally, into the zones of fear. Furthermore, naming the subject and the object of hate necessarily encourages feelings of empathy toward the subject and/or object of hate (the effects of empathy will be discussed later), and naming them can divert one's attention from the essence of the matter. ${ }^{5}$

In keeping with this, after considering the potential benefits and the potential harm, it is my opinion that the reader will not be deprived in any way if such examples are omitted, seeing that all of us (meaning all citizens of Croatia and/or those familiar with the Croatian context) have had the experience of reading/hearing hate speech, regardless of whether we were the object of hate; even if one lacks such experience, what this kind of speech looks like in (post)conflict societies can be imagined with relative ease. These are often explicit or - even more frequently - implicit invitations calling for extermination, rape, killing, injuring, maiming, disenfranchisement, exclusion, humiliation, banishment, or some other essentially illegal action directed against the object of hate (the possibilities or necessity of using legal sanctions against such behavior will not be discussed here), all based on a perceived belonging to a collective (which does not have to be the result of a choice made by the object of hate). The implicitness of the calls for such actions partially obscures the nature of the utterances themselves, thereby allowing for the characterization of an utterance as hate speech to be disputed.

Rather than debating the exponents of such speech, the fundamental goal of this paper is to theoretically articulate the questions raised by this sort of material (and offer answers, if only partially). Researching hate speech and the language of hate in Croatia is a rewarding undertaking, because there is certainly no lack of it. Everyday life is saturated with it to the point of becoming unbearable, primarily for the objects of hate, but also for all those who see a pluralistic society as a community value. However, it is precisely its frequency, and especially the wide acceptance of hate speech, that creates discomfort for anyone who wishes to approach the issue from a theoretical or analytical standpoint. This unease is the result of the dominant affective atmosphere, which will be discussed later. Researchers must work within this atmosphere, but they also help shape it in accordance with the scope of their influence and their personal and professional habitus - not just by disrupting the cog-

\footnotetext{
${ }^{5}$ This mechanism is depicted in a very interesting way in an opinion piece by Boris Dežulović, in which the crime is described without naming either the victims or those who committed the crime. In the article, Dežulović "hides" their identities to "relieve the reader of the burden" of empathising with "their own kind". The text, titled "It's up to You" ("Na vama je"), ends with the following segment: "Of course I will not tell you where the massacre from the beginning of the story took place. It happened. [... Perhaps it was our boys and our generals, and perhaps the old woman with the crushed skull was one of us. Perhaps she was, perhaps she was not" (http://hr.nlinfo.com/ a162144/Kolumne/Boris-Dezulovic/Na-vama-je.html, accessed 8. 6. 2018).
} 
nitive tranquility of the community (Zerubavel 2006: 74) but also by being prone to some form of silence. In that sense, some researchers are more prepared for the par excellance act of morality, as Zerubavel (ibid.: 86) calls the interruption of the conspiracy of silence to which he had not subscribed, while others, e.g. the interlocutor who convinced me that my decision was right, believe that:

$[\mathrm{t}]$ here is $[\ldots]$ so much noise around us at the moment that there is no point in talking about our experiences and feelings. We haven't yet reached a point at which we're able to accept it. Not even a single, tiny, quiet voice can be heard. [... Currently, it's pointless. No one will see what it's really all about. Everything is superficial. Everyone reads the headlines. No one is going to look into them more closely, but lines will be drawn based on the headlines alone. (a 70-year-old man from Pula)

Due to these unfortunate circumstances, I will neither name specific subjects and objects of hate and fear, nor will I discuss the groups they belong to. ${ }^{6}$ After all, from a theoretical perspective, the problem is a universal one. All wars are complex, and affective practice and policies during wartime and in the post-war period are often rather similar across different socio-cultural contexts.

\section{Hate speech}

The question in the title of the paper is a metaphorical one and is paraphrased from the title of the conference "Words that Kill", at which this paper was presented. ${ }^{7}$ It supports the fundamental idea of the paper, which is that hate speech is not only destructive for individuals (the senders and the implied recipients of the message) but also for the whole community. The title of the paper suggests that it will primarily deal with silence, one which arises from hate and is managed by fear, and also one which arises from fear and is managed by hate. The idea I would like to put forward in this paper is that it is primarily fear, and frequently also hate, which is narrated and communicated through an absence of verbalization, despite hate being, as it seems, more "garrulous".

I differentiate between the language of hate and hate speech in a de Saussureesque manner. The language of hate is therefore a system, a discourse which precedes hate speech. Language is "the basis on which agents construct the social

\footnotetext{
${ }^{6} \mathrm{I}$ found support for this in the decisions made by two authors who, when writing their studies, clearly stated they would not provide any examples. My reasons are largely similar to theirs. Eviatar Zerubavel (2006) did so in his study on denial and conspiracy of silence in certain communities. In the case of Kevin Saunders (2011), it was a study on degradation and hate speech. Their decision, at least in my opinion, did not make their studies any less brave in tackling important social issues and problems, did not make them methodologically flawed, and it certainly did not make them any less credible.

${ }^{7}$ The paper was initially presented in a much shorter form at the "Words that Kill" conference. The conference was organised by the George and Irina Schaeffer Center for the Study of Genocide, Human Rights and Conflict Prevention and took place in Paris from 28 to 30 May 2018.
} 
world" (Besnier 2009: 3). Hate speech is the specific use of language, the actual utterance. It is an external manifestation of the langue of hate (cf. de Saussure 2011 [1893]). Extreme forms of hate speech are deliberately abusive, insulting, threatening, demeaning, directed at members of a particular group, and calculated to stir up hatred against them (cf. Waldron 2012: 9). Forms of speech are deeply linked to social dynamics, and their relation is often ideologically shaped. By extension, our assessment of what constitutes hate speech and what could be described as an "ordinary" dislike or disagreement is only partially arbitrary and is closely related to the desirable and dominant affective policies, the context of such speech, the affective atmosphere in which the utterance occurred, and the habitus of both the speaker and the recipient. The concept of hate speech is most frequently used in publications dealing with the legality of particular speech acts or the legal regulation of such speech in general. Therefore, the concept of hate speech is often used as a legal term (cf. Waldron 2012). In cultural anthropology and folklore research, the concept is not acknowledged in an analytically explicit manner, at least to my knowledge.

The linguist and philosopher Gerald Posselt defines problematic forms of speech that can lead to hate crimes as "forms of hate speech, inflammatory speech, or incitement of hatred" (Posselt 2017: 6). In the article "Can Hatred Speak? On the Linguistic Dimensions of Hate Crime", Posselt discusses the intrinsic relation of language and violence. He puts forward a hypothesis based on a case study of a verdict issued by the ICTY (International Criminal Tribunal for the Former Yugoslavia) that "it is possible neither to gain an adequate understanding of speech and language without considering their violent force, nor to gain an adequate account of interpersonal violence without considering its linguistic-symbolic dimension" (ibid.: 7). He believes that

hate speech as well as hate crime have to be considered as speech and as action, i.e., as a speech act in the strict sense of the word that is intertwined with certain actions and activities as well as an act that expresses a particular meaning. Furthermore, if hate crime "speaks" and conveys a common message that must be listened and answered to, remarkably language itself seems to provide the vocabulary to illustrate the effects of physical violence. (ibid.: 18)

In this paper, the concept of hate speech is not used in a legal sense but is instead determined in a more arbitrary manner. Here it refers to speech that has this type of effect on its object, even if such effects are not recognized or sanctioned by the legal system. An utterance calling for harm toward a certain group does not have to be seen as hate speech by all those participating in communication (in the case of the speaker, it can be a consequence of objectifying the victim of hate speech); likewise, in judicial practice, there is no uniform interpretation of hate speech, and the legal systems of different countries handle it differently (cf. Waldron 2012; Posselt 2017). ${ }^{8}$ I sometimes use the concepts of exclusionary speech and discrimination for utterances which are not as "charged" and which have a weaker effect. The bounda-

\footnotetext{
${ }^{8}$ The most vibrant debate is taking place in the USA, and it is centred around the issue of how hate speech is understood within the context of freedom of speech (Waldron 2012).
} 
ries between these types of speech are also arbitrary and are based on the assumed effect they have on the object. For example, the language of exclusion or omission is not, in this sense, treated in this paper as hate speech, but there is an awareness of the fact that it increases the sensitivity of the object of hate to such speech. One interlocutor described her definition of hate speech and how it differs from other forms of verbal exclusion in the following way:

When you're living in a society in which it is normalized to say that you should be killed... You can write it on a wall, shout it at a stadium and so on... I mean, not that you personally should be killed, but your group. Well, I guess this also means to kill you ... That's how it goes? I'm then also bothered when they say on the news, without any bad intentions, that this-and-this number of Croats have taken a ski trip. As if there are only ethnic Croats living here. It would be funny to complain about something like that, but hate speech has the effect of generally reducing one's awareness that there are other people living here too, right? We should either be killed or at best, we aren't even here, or we're not talked about. (a 61-year-old woman from Zagreb)

In order to be able to study the conditions of narrating fear and the effects it in turn produces, I chose to focus primarily on places where there is an absence of or a reduction in verbalization - where silence appears as the consequence of the intimidating object and/or intimidated subject, i.e. their contact zones (Ahmed 2014). The language of hate and hate speech, as well as those who act as its vessels, i.e. the subjects of hate, are but an affective starting point - one that is ambivalent in the sense that emotions can also be reoriented (for example, the fearful object can become fearsome and vice-versa). When choosing the starting point for my analysis of the circulation of emotions (since basic emotions are always related to an object and are also in turn shaped by it), I focused on what is presented as being favored by the majority as dominant, politically empowered, and currently desirable. I will discuss some of the narrative forms and strategies used to give form to hate, e.g. conspiracy theories, gossip, personal narratives, and comments posted on social networks and websites, which are used to delineate, or in which the Other has already been delineated, as the object of hate. I will examine how hate is affected by the narrative and how hate enables the narrative to affect the object of hate. The emotionality of texts that use the language of hate helps me explain how texts "move" and how they can produce an effect. The focus on the emotionality of texts allows for insight into the experience of fear (or other emotions) and the narrative formation of fear of those designated as objects of hate. Silence plays a special role in communicating fear as well as hate.

Aided by cultural geographer Ben Anderson's (2009) concept of the affective atmosphere, I will problematize aspects of speech and silence generated by the affective atmosphere and also examine how the atmosphere itself is in turn shaped by speech and silence. I will attempt to answer the question of whether, and to what extent, the subject of anxiety/fear (which has been designated as the direct or indirect object 
of hate) can narrate their experience and emotional response to hate, especially considering that exposure to hate speech, which is the product of social tensions, most commonly is not a one-time occurrence. It is a repeated, often permanent, and lifelong experience, particularly in the case of minorities in societies marked by conflict.

\section{The affective atmosphere of hate, fear, and their silences}

In order to understand the language of exclusion and hate in the agoras mentioned in the introduction as well as the way in which emotions circulate, it is useful to apply the concept of affective atmosphere (Anderson 2009). The affective atmosphere in Croatia is understood to be the sum of the effects of dominant affective policies and interests, dominant and desirable affective behaviors, historical circumstances, and personal and familial war and post-war experiences and impressions, which have also been cognitively, emotionally, and narratively (re)shaped with the help of dominant affective policies and policies of remembering as they have changed over the course of history. The affective atmosphere is formed in all three agoras.

Anderson's concept of affective atmosphere is useful because it creates a space to articulate what he calls "a series of opposites - presence and absence, materiality and ideality, definite and indefinite, singularity and generality - in a relation of tension" (Anderson 2009: 77). Despite its shortcomings, the concept is useful specifically because it highlights the oppositions that suggest there is a continuum between the spoken and the unspoken, or in other words what is silenced in hate speech and the narrative formation of emotional responses from those designated as objects of hate. The concept is also useful because emphasizing oppositions allows us to see that the affective atmosphere of the post-war period (in Croatia, specifically) is closer to the pole which implies absence, incompleteness, instability, simplification, etc., thus making the atmosphere heavy, anxious, polarized, trench-like, progressively worse, hopeless, dangerous, and, finally, irreversible. Zerubavel (2010: 39) warns that silence becomes more prohibitive the longer it lasts.

Sara Ahmed believes that shared feelings surround us like an atmosphere and "these feelings not only heighten tension, they are also in tension" (Ahmed 2014: 11). The idea of an atmosphere in which shared feelings are in tension stems from the fundamental assumption that objects initiate emotions but at the same time also shape them. The subject thus becomes attached to the object, whether by attraction or repulsion (ibid.: 7). In the case of hate, for example, the issue is negative attachment (ibid.: 52). "The objects of emotion take shape as effects of circulation", as Ahmed would say (ibid.: 10). In the process, the object is always interpreted not only in accordance with the psychological and physical reactions of the subject but also through negotiation with desirable social and cultural patterns and group dynamics.

The tension produced by hate speech was described by Jeremy Waldron in the book The Harm in Hate Speech as a factor that undermines the public good, or "an 
open and welcoming atmosphere" (Waldron 2012: 16). Waldron believes that hate speech creates

an environmental threat to social peace, a sort of slow-acting poison, accumulating here and there, word by word, so that eventually it becomes harder and less natural for even the good-hearted members of the society to play their part in maintaining this public good. (ibid.: 4)

The gravity of the affective atmosphere in Croatia can be understood as a consequence of the "surpluses of history" (see also Sheftel 2013), a surplus of complex historical nodes (Bosto et al. 2008: 9) in which "the forces of the preceding history meet" and in which old and new conflicts simultaneously are resolved and multiply alongside the shaping of a new social and political reality (ibid.). Affective tensions are also increased because some events, like wars and significant moments during the wars themselves, are more in need of an explanation for their causes than others. In order to understand this need, "we need to realize how history itself shapes what begs explanation” (Bruckmüller et al. 2017: 270). The search for an explanation logically spills over into the present. The present is thus always saturated with past frustrations and delayed conflicts that continue to smolder until the next confrontation (cf. Bosto et al. 2008: 9). Fear presses members of affective communities into the future as an intense, physical experience in the present. Ergo, the object which we are afraid of does not precede or succeed us, but instead leaves an impression on us in the present in the form of anticipated future pain (cf. Ahmed 2014: 65). Evil is constantly expected, which ultimately results in an affective atmosphere that is fluid yet in some way still recognizable to all. This atmosphere acts as a vessel in which dominant affective policies as well as personal memories that support or oppose these policies are accumulated.

Wartime and the subsequent post-war period seem to be the "natural" environment, the "ideal" affective atmosphere in which the language of hate is enriched and creatively shaped, and in which hate speech becomes normalized. The emotionality of every individual narrative of the experience of war and the post-war period is constantly in tension with the emotionality of other, often "enemy" narratives of past experiences, because history resides inside every open wound in the present. Therefore, the affective atmosphere of the present consists of accumulated past experiences (both pleasant and unpleasant). "Harm has a history", as Ahmed would say. "Pain is not simply an effect of a history of harm"; it is the bodily life of that history (Ahmed 2014: 33, 34).

Margareth Wetherell (2013) modified and further defined the concept of the affective atmosphere (Anderson 2009), with particular criticism reserved for the notion that affective atmospheres are "subjectless" (Anderson 2009: 78). ${ }^{9}$ Wetherell gave preference to the term "affective practice" in order to gain better insight into the way in which "affective atmospheres organize subjectivity, and how affected subjec-

\footnotetext{
9 "Atmospheres are a class of experience that occur before and alongside the formation of subjectivity, across human and non-human materialities and in-between subject/object distinctions." (Anderson 2009: 78)
} 
tivities with particular histories can also actively work to bring about, alter, maintain, resist and challenge affective atmospheres" (Wetherell 2013: 235).

Certain features of affective practices, e.g. their "recognizable repetitions" (ibid.), ${ }^{10}$ show that it is possible, in an even narrower sense, to talk about affective narrative practices and folklore narrative patterns within which one can "alter, maintain, resist and challenge affective atmospheres" (ibid.). In affective narrative practices, silence has its place as the integral constituent element of every utterance and all human communication that has an identical or similar effect on the affective atmosphere as speech. "An affective practice approach", Wetherell believes, "takes as its focus and units of analysis patterns and cycles of activity that at a particular historical moment have become 'emotionalised' (understood through the conventional categories and vocabularies of emotion)" (ibid.).

The affective atmosphere is not primarily shaped from either above (high-level politics, historiography, and so on) or below (everyday narration of personal experiences); however, when coming from one of those directions, its intensity is amplified during certain historical periods (e.g. wartime and the post-war period). The affective atmosphere is not primarily shaped from any spectrum of affective tension, although the communication of certain emotions and affects can be clearer and have greater reach than that of others (hate is, perhaps, "louder" than fear, but it will not necessarily return as the fear of the object of the hate, etc.). Despite this, one could hardly say that the affective atmosphere is "subjectless", and that we are dealing with a prepersonal or transpersonal dimension of affective life and everyday experiences (Anderson 2009: 77). Rather, we could say that emotions circulate between bodies and that we cannot understand them outside of their social and cultural affective context or without understanding certain affective communities, their genesis, and their dynamics. Individual and collective affective processes should be seen as dynamic and mutually dependent in a constant process of negotiation, confirmation, and negation, i.e. in constant tension. Affective policies can therefore be understood as "the product of a relationship between various forms of action, from intimate contexts to events that involve the entire society" (Besnier 2009: 12).

\section{On hate speech and empathy}

As an act of communication, hate speech is based on hate toward a group, regardless of whether it is directed at an individual or at a collective. An important feature of hate speech, as described by Kevin Saunders is that it

is not the assertion of a degraded view of all of humanity. It is based on a belief that the target population whether on the basis of race, gender, or sexual ori-

\footnotetext{
10 "An affective practices approach is particularly focused on recognisable repetitions. The repetitions of practice, however, are rarely precise duplicates; they bear a more or less fuzzy resemblance to what has gone before." (Wetherell 2013: 235)
} 
entation, is of a lower order than the group to which the speaker belongs. It is a degradation to a less than fully human level of the subpopulation. It affords the dignity seen as properly due human beings to most of the population, while denying that dignity to its target group. (Saunders 2011: 196)

Hate speech - if not in a legal sense, then at least in a conceptual sense - is considered to stand for today's obscene depictions (ibid.: 6). ${ }^{11}$ The object of hate is interpreted as being emotionally regressive, unsophisticated, with a significantly inferior emotional response and inner life. The affective process of dehumanization, which is not simple, is key in hate speech. The object is not simply treated as less than human or non-human; rather, their humanity and dignity are concurrently acknowledged. This acknowledgment of the initial dignity of the object of hate makes it possible for the subject of hate to find pleasure in degrading them (cf. Bloom 2018: 205). This affective process is at the core of humiliation, stigmatization, torture, and verbal or physical abuse (ibid.: 206).

The moral undesirability of the language of hate, hate speech, dehumanization, and discrimination of the Other changes depending on the affective atmosphere (in our example, this is caused by the experiences of the war and post-war period), which can either reduce or increase the sensibility and moral criteria of the community. ${ }^{12}$ It should be emphasized that the escalations of the frequency of hate speech and its normalization are not simply the legacy of the past wars - the increased tolerance for hate speech is connected to the interests of particular groups in the present. For example, one interlocutor said:

You see, when $S[\ldots]$ was the prime minister, the atmosphere was normalized. There weren't as many incidents. It was an idyllic time [laughter]. He stole, but the image presented to Europe was idyllic. When $\mathrm{K}[\ldots]$ came to power, things got out of hand because riling up the lowest passions benefited him. They can exist only if there is an enemy. The only problem is that it's difficult to get the genie back into the bottle once it's released. (a 57-year-old man from Lika)

It would be incorrect to believe that the language of hate and/or hate speech result from a lack of empathy. Paul Bloom warned of this in his book Against Empathy (2018). Our moral choices and actions are strongly influenced by empathy, but empathy can also incite violence. Empathy can be manipulated. Empathy toward those who are close to us is a powerful force that can start wars and encourage atrocities against the Other (cf. Bloom 2018). Empathy can be the motive for committing acts of evil in the name of protecting the idea of superiority of one group over another.

\footnotetext{
${ }^{11}$ Saunders believes that hate speech currently "fills the role once played by pornography" (Saunders 2011: 73) and that it is, of course, degrading. He sees the degradation implicit in hate speech as "far worse than that represented by sexual obscenity" precisely because of the fact that hate speech is directed against a particular group of people, rather than the whole of humanity (ibid.: 196).

${ }^{12}$ The legal framework regulating affective behaviour, hate speech, and discrimination barely plays a role in the Croatian public sphere. The reasons for this are not just the effects of affective policies and the affective atmosphere, but also the inefficiency of the judicial system.
} 
However, empathy often comes with a boomerang effect. Due to the empathy they feel toward their own group and the injustice that has been committed against members of their group, a person who is part of a community that was at some point the target of dehumanization can later become the one performing the dehumanization of the Other. This is basically the mechanism of revenge. "Empathy can lead to anger; the empathy one feels toward an individual can fuel anger toward those who are cruel to that individual" (Bloom 2018: 208). "Anger feeds off the suffering of others" (ibid.: 209). Anger and empathy, Bloom believes, have "similar limitations" (ibid.: 210). Empathy with this type of orientation could be dubbed "sadistic". However, it could also be considered the socially desirable blocking of empathy toward the Other. Committing acts of evil does not necessarily have to mean that a person is low in empathy. Similarly, not committing acts of evil does not prove that a person is high in empathy.

As we have seen, the real object of hate speech is always the collective, even if the speech act itself is limited to only two people. The situation is similar with hate crimes. A hate crime sends a message to more than just the victim of the crime - it is also directed at the social group to which the victim belongs, at society in general, at people who support the act or those who sympathize with the victim. "This is possible because due to its linguistic-symbolic structure hate crime is able to break with its context and to transcend the concrete scene of address" (Posselt 2017: 16). This idea was explained by a 70-year-old woman from Pula:

I find listening to stories about our children and your children the most difficult, the most nauseating, and the most disgusting. If you mention $\mathrm{A}[\ldots]$ $\mathrm{Z}[\ldots]$, you immediately get the response: "But what about thousands of our own children?" For goodness' sake, as if it's normal for even one child to get hurt and taken to Sljeme or some other place to be killed.

Posselt identified a constitutive linguistic dimension to hate crimes and hate speech, i.e. their iterative and citational as well as transformative-performative structure (Posselt 2017: 16). Hate speech and hate crime "have the potential to harm and injure others, even beyond the concrete scene of address", which results from the fact that they, "both as speech and as act [...], invoke past injuries and traumas that are historically sedimented in the norms, structures and conventions of language and social institutions" (ibid.: 17).

Hate cannot be reduced to a particular body, which allows it "to circulate $[\ldots]$ working to differentiate some others from other others, a differentiation that is never 'over', thus giving legitimacy to repeating acts of violence in the name of protecting the community (Ahmed 2014: 47).

An idealized view of what is human in humanity, especially in so-called liberal democracies, is provided by Martha Nussbaum, who believes that the recognition of humanity across the board is the ultimate ethical act (Nussbaum 2001: 334). However, empathy can be a powerful driving force behind evil. It has a precarious status and is marked by unreliability and intentional withdrawal. Empathy is a "complex 
and dialectic process that includes also its opposite: states of psychic numbing, of desensitization" (Assmann and Detmers 2016: 9). Empathy is also shaped by powerful mechanisms which determine the flowing or blocking of empathy, as pointed out by Judith Butler (2009) when she introduced the term "grievability" as a critical concept. These mechanisms are often managed through the dominant politics of empathy, which change over the course of history (see Frevert 2011, 2016). The greatest danger posed by hate speech lies in the fact that the "silent majority" can become indifferent and desensitized to it or can be intimidated into silence. How does this happen?

\section{From public discourse to personal narratives and back}

In contemporary Croatia, acts of speaking undertaken by public figures in the "verbal marketplace" are not characterized by the self-management of affects in affective performances directed toward minorities or those who think differently (statements, public appearances, etc.), and the reason for this is not necessarily a lack of empathy. Public figures who have the power to influence political processes in Croatia, as befits their profession, very rarely manage their emotions and can hardly be described as an "emotional proletariat" (Macdonald and Siriani 1996: 3 and onwards; see also Hochschild 2012). Their articulation of emotions is often uncontrollable when it comes to minorities or those who do not share their views, and/or who are designated as objects of hate in the manner which Antonio Damasio (1999: 49) compared to sneezing. It is their contribution to the affective atmosphere.

Communication on social networks and comments posted in response to articles published on various websites have an influence on and can potentially shape the affective atmosphere. ${ }^{13}$ These forms of communication can be seen as oral communication that leaves a written trace in real time, and which provokes and incites reaction. Comments are most strongly characterized by an absence of any sort of censorship or self-censorship, which allows for clearer insight into social relations, the language of hate and its spoken realizations, speech acts, the processes through which the Other is imagined to be dangerous, intimidating, repugnant, disgusting, sick and immoral, collective fears and aspirations, personal frustrations, unfinished narratives on past and future conflicts, and also the genres through which all of this is shaped. Communication on social networks and in the comments below articles is rife with forms which could be characterized as cyber-bullying and harassment, and some groups could even be described as "virtual training camps" for hate crimes (cf. Posselt 2017: 17).

\footnotetext{
${ }^{13}$ As mentioned in the introduction, I will not list examples, but I can point the reader's attention to any website (both those advocating extreme and those advocating moderate ideas), along with the articles and the associated comments published there that deal with minority issues, sporting or cultural events, protests, certain public figures, etc. (the websites I visited over the past three years are listed under footnote no. 2).
} 
From the public sphere, the language of hate spills over into everyday oral and written communication - as well as vice-versa - and is realized in many oral genres.

Exclusionary and hate speech is frequently shaped in media and oral communication through the genre of conspiracy theories. ${ }^{14}$ Hate speech can be understood as the kind of conspiracy theorizing done by political extremists, as Bratich believes (2008: 13). ${ }^{15}$ Hate speech, he maintains, is often coupled with "sensational stories, gossip, and untrustworthy information as the perceived content of nonprofessional channels" (ibid.: 67). Therefore, it is both shaped and dissolved in everyday communication, on social networks, and on websites. However, conspiracy theories are a much more complex genre which can have both defensive and offensive functions in relation to official knowledge. Conspiracy theories can be analyzed beyond the opposition between delusion and concealed truth (Blanuša 2011a; Marković 2018). Conspiracy theories are often where fear is narratively shaped and where a paranoid (although not necessarily delusional) response to hate is provided. Hate speech, in this sense, should definitely not be included in the definition of conspiracy theories, but from a narratological standpoint, there is no doubt about them being open to hate speech.

Although he did not refer to them as such, one of my interlocutors made the following comment about conspiracy theories:

It all started with the black, green and red devils, ${ }^{16}$ then it continued with Bolshevik Satanists, Yugonostalgics, recycled communists and what not. G[... $]^{17}$ even talked about Communist Youth girls ${ }^{18}$ with unshaved legs. It remains unknown who these people are, these enemies. Who are the Communist Youth girls? Who are the Satanists? What is this? Where do they see Yugoslavs today? If you don't think like them, you immediately receive threats, you should be impaled on a stake. It doesn't even matter if you are a Croat, a Catholic. It's only important that they see you as redundant, that what you think is what isn't allowed. And we, we don't even have to think. Whether we think or not, it's all the same for us. (a 50-year-old man from Lika)

Gossip is a genre with significant potential for shaping exclusionary and hate speech. ${ }^{19}$ In his book, Gossip and the Everyday Production of Politics, Niko Besnier puts forward the idea that "intimate events and experiences are intertwined with

\footnotetext{
14 "New media and formats, the home to conspiracy theory-fuelled patriots and hateful speech, functioned as the Other by which to define public journalism" (Bratich 2008: 73). More information on conspiracy theories is available in, for example, Blanuša 2011b; Marjanić 2016; Bratich 2008; Marković 2018.

15 "In the militias, one could find the figure of extremism par excellence: the dangerous hybrid of hate speech and violent action." (Bratich 2008: 13)

${ }^{16}$ The practice of referring to one's enemies as devils (red, green and yellow devils) comes from the first Croatian president, Franjo Tuđman (1996). Video: https://www.youtube.com/watch?v=jIppnU2nKBc (accessed 9. 10. 2018).

${ }^{17}$ A member of the Croatian parliament.

${ }^{18}$ Women belonging to the now defunct League of Communist Youth of Yugoslavia (SKOJ), the youth organisation of the Communist Party of Yugoslavia.

${ }^{19}$ More information on the genre is available in, for example, Birchall 2006; Bergmann 1993; Besnier 2009.
} 
large-scale processes" (Besnier 2009: 2). Gossip is a form of agentive action and is also a suitable tool for political action in private realms (ibid.: 12).

Gossip in which hate speech is implicitly or explicitly used, or in which the object of hate speech is defined and interpreted can have far-reaching consequences for its victims.

In this context, let us consider following example:

Somebody at work revealed my ancestry to my mother-in-law. They never heard it from me because that part of my identity isn't important to me. I don't point it out. I don't mention it. I mean, who cares? Anyway, the woman went crazy, started crying. She was deeply unhappy. She didn't even know me, but that information was enough for her to allow them to humiliate me every time. And my child. Directly, this meant that I wasn't even offered water when we came to visit, and indirectly... When there was some sort of party at their house, my brother-in-law would be there, for example... He would start talking about some person, a singer or someone like that, and he would say that $[\ldots]^{20}$ are not people, that they should be killed, that they are garbage, shit. As if it didn't have anything to do with me, but it most certainly did. He thought he was humiliating me, but he wouldn't address me. I never said a word. That would provoke him even more. I found it funny and sad and nauseating. One time, my mother-in-law said to my niece that they wouldn't give me a puppy because I am a $[\ldots]^{21}$. I also heard that my brother-in-law got drunk in some bar once and started shouting that I was a $[\ldots]^{22}$ whore, that his brother was an arrogant prick and all sorts of other things. We aren't in touch at all any more. The best part is that we never even talked about this. They aren't even aware that I know these stories. (a 40-year-old woman from Pula)

In the case of gossip, there is a noticeable disproportion between its social assessment as a trivial verbal activity and the seriousness of its potential consequences, which can turn it into a powerful political tool that can easily become an instrument of oppression used to establish, expand or maintain the continuity of pre-existing inequalities and to control the material and symbolic resources which have hate toward the Other as their basis (cf. Besnier 2009: 17). Gossip is characterized by the emotionality of the text and its emotional effect: the target of gossip most often experiences shame, fear, or sadness while the gossipers experience pleasure (ibid.: 18). The narrative practices of exclusion and hate can be achieved in gossip, which, despite being a multiparty production, can keep the object of hate silenced. It cannot be said with certainty whether gossip is based on an underlying personal conflict or stands as a reflection of some sort of conflict between collectives (races, classes, nations, genders, etc.). This feature makes it useful for shaping hate speech and exclusion on the grounds of belonging to a more or less imagined or real community, despite the fact that it deals with a specific person, which is the object of hate speech.

${ }^{20}$ The name of the ethnic group has been omitted.

${ }^{21}$ The ethnic background has been omitted.

${ }^{22}$ An adjective derived from the name of an ethnic group has been omitted. 
Personal narratives, especially those which thematize the difficult experience of war, war trauma, etc., are also characterized by the emotionality of the text and can have the function of proving legitimacy for a future articulation of hate toward the Other; however, they also serve as a container for the accumulation of fear, frequently in the form of silence. Personal narratives clearly show that violence is not just the violation and injury of a bodily self; instead, it is equally directed against "the identity and continuity of persons as agents of significant and binding actions" (Posselt 2017: 16). In the case of the previous example, which reveals the role gossip plays in shaping hate and in the way it affects its object, it is evident hate speech also affects family relationships. It interrupts and destroys the continuity of relationships and roles, and it leaves all those participating in communication in silence. Personal narratives, regardless of how many things remain unsaid, inform us about the effects of verbal violence, and a wide array of emotional responses to hate can be found within them.

\section{Hate, fear, and their silences}

The discussion has so far been focused on the ways hate speech is produced through affective narrative practices and in different genres, in both public discourse and everyday communication. The focus of the remainder of this paper will be on how the language of hate affects those who are designated as objects of hate, and the degree to which the subject of anxiety/fear (i.e. the explicit object of hate) can narrate their experience and emotional response to hate. I will also attempt to provide an answer to the metaphorical question from the title: can silence, as a response to hate, symbolically "kill" the individual (the object of hate), or in other words, can silence only be defined as negatively marked absence with necessarily negative and harmful consequences? This question also raises new ones: Can silence, as a response to hate speech, be seen as the symbolic "suicide" of the object of hate? If we consider hate speech to be a form dominated by the silencing of the essential, is it also simultaneously the symbolic "murder" of the object of hate and the "suicide" of the speaker?

It would not require great difficulty to reach an agreement regarding the idea that words can kill or that language can, at the very least, incite violence. Hate speech serves as "foreplay" for violence, but it also frequently emerges as its consequence, i.e. a reminder and the residue of violence. Hate speech frightens the objects of hate because they are aware that verbal violence can become reality in the form of physical violence, whereby its assumptions are based on a history of violence. One interlocutor stated on numerous occasions: "They can only kill me once. No more than that" (a 55-year-old woman from Lika). Along with this statement, she would also repeat that she was not afraid of anyone and that she did not hate anyone. She sees the affective atmosphere around her as threatening, and she obviously sees physical threats and physical violence as an option and as a possible resolution of the tension she is sensing. 
Gerald Posselt warned of the connection between violence and hate speech and between their inherent silence and the language they use, when he stated that

[h] ate crime does not only imply a fundamentally linguistic-symbolic dimension, rather it is directed against the possibility of language and speech itself, against the possibility of speech to make sense and to perform significant actions. (Posselt 2017: 18)

Being aware of the violence perpetrated against people belonging to the interlocutor's ethnic group, along with being aware of the violence perpetrated by her own people that could be considered a hate crime, means to expect new violence which is, at the moment, "only" being manifested verbally. Paradoxically, the hate crimes which have already been committed "speak", while also simultaneously "undermin[ing] [... the possibility of speech itself" (ibid.). It results from this paradox, Posselt believes,

that violence is both the condition of possibility and the condition of impossibility of speech. It is, so to speak, the condition of possibility of speech, insofar as neither sense nor meaning would be possible without an act of naming that makes something recognizable, identifiable, or addressable as something in the first place. [...] It is the condition of impossibility, insofar as it undermines the very possibility of speech itself, namely, inasmuch as it aims at making us speechless, depriving us of the possibility of speaking out and being heard. (ibid.)

The experience of physical or symbolic verbal violence most often renders us speechless and unable to find a sensible response. The effect of specific, individual hate speech on the victim is more often visceral than intellectual. This is why it has negative effects on the body. It is mutually visceral since it reflects the visceral repulsion of the sender and manifests their internal rage, frustration, bias, fear, and anxiety (cf. Saunders 2011: 132), while also triggering visceral repulsion in the listener/ reader/viewer, which can manifest itself as fear, anxiety, isolation, powerlessness, a reduced need for intersubjectivity, etc., but also as anger, rage, empathy, blocking of empathy, etc. Long-term or life-long exposure to hate speech and intolerance, as well as the affective atmosphere which produces it (or at least which fails to condemn it), along with fear, anxiety, sadness, a feeling of powerlessness, isolation, humiliation, as well as with resistance and defiance, can have numerous other emotional, cognitive, physical, and intellectual consequences.

The following are several examples from my research in which the interlocutors expressed the bodily sensations they experienced in response to hate speech, discrimination, and exclusion in narrative form:

In a crowd of people... When I'm in a crowd, I sometimes wonder what would happen if who I am was written on my forehead. I think that if the others knew, they would surely insult me or beat me up. I get distressed. I feel my gut clenching, there is pressure in my head. (a 50-year-old woman from Pula) 
When I hear disgusting things like that, I want to throw up. My stomach turns. It's as if I start breathing more shallowly. I start panting in a way. Shallowly. That's why I don't read the news, I don't watch TV. (a 24-year-old woman from Lika)

You can't go against hate. How? How am I supposed to convince a bully that he is acting like one? I feel like I would become exhausted from trying to explain it, I wouldn't accomplish anything, and I'd probably get beat up. There is no arguing with hate. There isn't. (a 68-year-old woman from Pula)

I read this muck [comments on social networks and websites]. Probably some sort of sadism. I have no idea. I ended up feeling sick after reading some of these debates. It was that kind of day for me. Maybe it was just a viral infection [laughter]. (a 42-year-old woman from Pula)

Well, what do you think - why did my parents fall ill? Because of love? (a 55-year-old woman from Lika)

What all these sensations experienced by the object of hate have in common is the feature of being difficult to express and narratively shape in everyday communication, as language is sometimes not enough to express the physical and mental pain residing inside the object of hate. In her book, The Body in Pain, Elaine Scarry claims that pain (both physical and mental) is not only bodily trauma; it also resists or even "shatters" langue and communication (Scarry 1985: 5). All communication, as observed by Adam Jaworski (1993), has silence at one and talk at the other end of its continuum. The communication of hate, as well as the communication of an affective response to hate by the object of hate, are no exceptions. However, both the subject and the object of hate are closer to the end marked by silence, or at least a partial absence of speech, and by extension, the inability to narratively shape communication.

Speech and silence should be considered "morally neutral" because "[b] oth can be deployed in morally defensible and in morally deplorable ways" (Winter 2010: 10). Consequentially, speech and silence cannot be unambiguously associated with either the aggressor or the victim.

At first glance, it seems that the language of hate is "garrulous", and that it has a need to realize itself through speech acts. However, if we take a closer look, it becomes obvious that exclusionary and hate speech, i.e. aggressive speech, should be understood to be (self-)censored, synecdochical, concise, misunderstood, uncontextualized, or miscontextualized, sometimes inexpressible, imprecise, undefined, generalized, overdetermined, difficult to communicate, reduced, redundant, and metaphorical. These attributes of hate speech can manifest themselves as noise pollution, logorrhoea, or "garrulous silence" in which speaking serves as the "carapace of speech" (Kenny 2011: x). Furthermore, hate speech does not require and does not want communication. Rather than dialogically, it is more often monologically oriented. Hate speech is often communicated indirectly; the response to hate speech is frequently left unarticulated and takes place in an entirely different environment 
(e.g. within the family, in psychotherapy, etc.). This is why the subject of hate does not have to notice the silence of the object, which does not mean that this silence does not exist. It can be articulated in other places and in communication with other people, like in the following example:

I had this tragicomic situation at work. One of my co-workers, who is usually a kind person whom I've never had any disputes with... She was particularly inspired one day. We were talking about all sorts of unrelated things... She burst into a soliloquy about $[\ldots]^{23}$, how they should all be banished to $[\ldots]^{24}$. Does she go to their land, what are they doing here? Nothing but problems with them. They should go back to where they came from. That's what we fought for. I tried to explain to her that these people had always lived here, that they had been born here, that many of them had never done anything bad to anyone. She stuck to her opinions. I knew that many people had thoughts like this, but it was especially uncomfortable to listen to her because she was speaking honestly, and she wasn't aware that she was also talking about me. If she knew, I'm sure she wouldn't have said that, even though she believed it. It was a strange experience. Very strange. She hates you and she doesn't even know that she hates you. A bit schizophrenic. I didn't take it personally, but I can't say that I wasn't upset by it. (a 50-year-old woman from Pula)

Hate speech can be the final word in the history of contact between the subject and the object, despite it never being so. It undermines further communication, silences its object, and attempts to symbolically remove it from communication. By doing so, it also finds itself within the zone of silence. An attempt to continue communication by a person who was designated as the object of hate, or some empathic or nonconforming subject who belongs to the imaginary community of subjects of hate, produces a whole new wave of exclusion and hatred, where the victim, by choosing to continue the communication, finds themselves in an even worse position and is exposed to even more vicious attacks.

Hate speech can be seen as an eruption "from the underground of silence", as observed by Max Picard, who also added that " $\mathrm{t}]$ he word that comes from silence is in danger of contact with the destructive and demonic power that is in silence" (Picard 1964: 36). In other words, hate speech is not as dangerous because of what is uttered but because of what remains unsaid.

When the "silent majority" ignores hate speech, this should be understood as a strategy used by the subjects to align with the collective "by attributing 'others' as the 'source' of [their] feelings" (Ahmed 2014: 1). The goal of the dominant affective policy is to control affective practice - subjects who do not align with the collective must, therefore, suffer consequences. One of my interlocutors referred to such people as "good neighbors", i.e. those who hide their empathy from the group and strive to mitigate the harm suffered by the victim even at the expense of their own suffer-

${ }^{23}$ The name of the ethnic group has been omitted.

${ }^{24}$ The name of the country in which the ethnic group mentioned earlier is the majority has been omitted. 
ing. Silence breakers, whether they are the primary objects of hate or just bothered by hate speech despite not being directly affected by it, can be aggressively silenced, ridiculed, or vilified, and are often ostracized from the community (cf. Zerubavel 2006: 72). Retaliation tactics like these can intimidate and silence even those who "might contemplate breaking the silence" (ibid.). It seems that, at first glance, the only possible response to exclusionary speech and hate speech is silence.

I find this claim dangerous. Accepting such an idea would mean the betrayal of those who live, communicate, and suffer in silence. Even though silence can provide refuge (most often a temporary one), whether due to shame, fear, or a similar reason (cf. Kenny 2011: 20), we are still dealing with pathological and pathologizing processes. Extreme hatred toward members of a particular group may not be recognized as a mental disorder, but the "silent majority", and especially the targets of the attack, regard the subjects of hate as dangerous and see their behavior as a sign of an unhealthy mind (cf. Saunders 2011: 167). Likewise, psychotherapeutic practice has shown that those designated as objects of hate are more prone to suffering from both mental disorders and physical illnesses.

However, it would be wrong to claim that silence is simply negatively marked absence. It is not necessarily a sign of "psychopathologized processes of avoidance and repression, socially suspect processes of personal secrecy, or collective processes of political subjugation" (Kidron 2009: 6). Logocentric interpretations of silence overlook the role silence plays as a medium independent from speech for expression, communication, and the transfer of knowledge. At the moment, there are two main approaches to studying silence (see, for example, Pagis 2010: 312). One sees silence as the consequence of oppression and a conspiracy of silence, in which silence is understood as the denial of voice, or in other words in which remaining speechless means being silenced (Zerubavel 2006). The other approach sees silence as a meaningful and constitutive environment.

According to the first approach, silence is seen as a powerful psychological burden (Butler 1982) and speech is associated with the effect of bringing release from fear and anxiety. The concept of narration as curative stems from this approach. This idea postulates that silence related to trauma is discursively shaped as the stifling of speech, stemming from the unspeakable nature of an experience which is beyond narration, rather than one's personal will. However, this is not the only reason why we remain silent. We stay silent because we are afraid that we will not be believed, and that our fear will be belittled. We are fearful that showing fear results in an image of ourselves as someone who has reason to be afraid. For example, we remain silent when we are guilty or when we are afraid that our innocence is being doubted. But silence can also be a strategy of ignoring the speaker of hate - a form of avoidance that tries to diminish the influence of hate speech by refusing to become involved in the ongoing vicious circle of verbal or physical violence. If we consider hate speech to be a procedure for exclusion from the community, it would be possible to say that silence is more than just simple withdrawal - it is withdrawal from inappropriate 
communication and the procedure of exclusion as well. This thesis is supported by one of my interlocutors, who said:

Society is not ready to face the writing on the wall, let alone what was left unsaid and what isn't known, the things I could talk to you about for days. (a 68-year-old man from Lika)

Silence, as a consequence of being targeted by hate speech - as a response to it, should be seen as an affective practice integral to and inseparable from all communication and every speech act. Silence is a part of language, not its opposite. The extreme advocated by the latter approach to silence highlights the notion that silence is used to channel forms of knowledge which resist articulation and collective inscription, but which appear as non-verbal, intersubjective, embodied, and material traces of past experiences in everyday life (Kidron 2009: 7). Ergo, silence is effective.

The silence which results from hate speech might seem invisible from the dominant perspective, but it is in reality a rich world that is hardly marked by absence. Even though these are silences which are rarely registered in the public space, this does not mean they do not exist, they are not used to communicate, and they are not sometimes, and in some places, very clearly verbalized.

My kids joke around when it comes to this ${ }^{25}$. Once, when we were leaving the house, the boy said, "let's go, people and $[\ldots]^{26 "}$. He then burst out laughing. They know who we are and where we are. (a 48-year-old woman from Pula)

This example illustrates how the emotional response to hate speech and the processes of dehumanization, which is often left unarticulated in the public space, can manifest itself in the family environment in a humorous form or in the form of an auto-ironic stance toward one's own social position and the dominant affective atmosphere.

From this perspective, it would seem that silence does not kill. As long as there is at least one person left to experience or register silence, it will be a constitutive environment (cf. Kenny 2011: 70). The minimum that must be met for silence to not "kill" us is that someone has to notice its existence, because silence (just like speech) is a form of resistance - and resistance is a certain, unambiguous sign of life. This idea is also the source of my need, as a researcher, to act as witness to the numerous silences that few people are willing to listen to. Metaphorically speaking, while conducting fieldwork, it would often seem to me that this was an act of "(self-)salvation" for the life I was acting as a witness to.

\footnotetext{
${ }^{25}$ The hate directed towards them.

${ }^{26}$ The name of the ethnic group has been omitted.
} 


\section{REFERENCES}

Ahmed, Sara. 2014. The Cultural Politics of Emotion. Edinburgh: Edinburgh University Press.

Anderson, Ben. 2009. "Affective Atmospheres". Emotion, Space and Society 2/2: 77-81.

Assmann, Aleida and Ines Detmers. 2016. "Introduction”. In Empathy and Its Limits. Aleida Assmann and Ines Detmers, eds. Basingstoke, New York: Palgrave Macmillan, 1-17. https://doi.org/10.1057/9781137552372_1

Bergmann, Jörg R. 1993. Discreet Indiscretions. The Social Organization of Gossip. New York: Aldine De Gruyter.

Besnier, Niko. 2009. Gossip and the Everyday Production of Politics. Honolulu: University of Hawai'i Press. https:// doi.org/10.21313/hawaii/9780824833381.001.0001

Birchall, Clare. 2006. Knowledge Goes Pop. From Conspiracy Theory to Gossip. Oxford, New York: Berg. https://doi. org/10.26530/OAPEN_390769

Blanuša, Nebojša. 2011a. "Depathologized Conspiracy Theories and Cynical Reason. Discursive Positions and Phantasmatic Structures”. Politička misao 48/1: 94-107.

Blanuša, Nebojša. 2011b. Teorije zavjera i hrvatska politička zbilja 1980. - 2007. Zagreb: Plejada.

Bloom, Paul. 2018. Against Empathy. A Case for Rational Compassion. London: Vintage.

Bosto, Sulejman, Tihomir Cipek and Olivera Milosavljević. 2008. "Povijesni lomovi. 1941. u sjećanju nacijā”. In Kultura sjećanja: 1941. Povijesni lomovi i svladavanje prošlosti. Sulejman Bosto, Tihomir Cipek and Olivera Milosavljević, eds. Zagreb: Disput, 7-10.

Bratich, Jack Z. 2008. Conspiracy Panics. Political Rationality and Popular Culture. New York: State University of New York Press.

Bruckmüller, Susanne, Peter Hegarty, Karl Halvor Teigen and Gisela Böhm. 2017. "When do Past Events Require Explanation? Insights from Social Psychology”. Memory Studies 10/3: 261-273. https://doi. org/10.1177/1750698017701607

Butler, Judith. 2009. Frames of War. When Is Life Grievable? London, New York: Verso.

Butler, Sandra. 1982. Conspiracy of Silence. The Trauma of Incest. San Francisco: Volcano Press.

Damasio, Antonio R. 1999. The Feeling of What Happens. Body and Emotion in the Making of Consciousness. New York: Harcourt Brace and Company.

de Saussure, Ferdinand. 2011. Course in General Linguistics. Perry Meisel and Haun Saussy, eds. Translated by Wade Baskin. New York: Columbia University Press.

Foley, John Miles. 2012. Oral Tradition and the Internet. Pathways of the Mind. University of Illinois Press.

Frevert, Ute. 2011. Emotions in History. Lost and Found. Budapest, New York: Central European University Press. https://doi.org/10.7829/9786155053344Frevert

Frevert, Ute. 2016. "Empathy in the Theater of Horror, or Civilizing the Human Heart”. In Empathy and its Limits. Aleida Assmann and Ines Detmers, eds. New York: Palgrave, 79-99.

Hochschild, Arlie Russell. 2012. The Managed Heart. Commercialization of Human Feeling. Berkeley, Los Angeles, London: University of California Press.

Jaworski, Adam. 1993. Power of Silence. Social and Pragmatic Perspectives. London: Sage. https://doi. org/10.4135/9781483325460

Kenny, Colum. 2011. The Power of Silence. Silent Communication in Daily Life. London: Karnac Books.

Kidron, Carol A. 2009. "Toward an Ethnography of Silence. The Lived Presence of the Past in the Everyday Life of Holocaust Trauma Survivors and Their Descendants in Israel". Current Anthropology 50/1: 5-27. https://doi. org $/ 10.1086 / 595623$

Lozica, Ivan. 1979. “Metateorija u folkloristici i filozofija umjetnosti”. Narodna umjetnost 16: 33-55.

Macdonald, Cameron Lynne and Carmen Siriani. 1996. "The Service Society and the Changing Experience of Work”. In Working in the Service Society. Cameron Lynne Macdonald and Carmen Siriani, eds. Philadelphia: Temple University Press, 1-26.

Marjanić, Suzana. 2016. “Teorije zavjera kao urbane predaje/legende s paranoidnom matricom”. Narodna umjetnost 53/2: 111-131. https://doi.org/10.15176/vol53no207

Marković, Jelena. 2018. "Conspiracy Theory and (Not) Belonging. Experiences of War, Displacement and Estrangement”. Studia ethnologica Croatica 30 (in print).

Nussbaum, Martha. 2001. Upheavals of Thought. The Intelligence of Emotions. Cambridge: Cambridge University Press. https://doi.org/10.1017/CBO9780511840715

Pagis, Michal. 2010. "Producing Intersubjectivity in Silence. An Ethnographic Study of Meditation Practice". Ethnography 11/2: 309-328. https://doi.org/10.1177/1466138109339041

Picard, Max. 1964. The World of Silence. Chicago: Henry Regnery Company. https://herbertbaioco.files.wordpress. com/2017/02/the-world-of-silence-max-picard.pdf.

Posselt, Gerald. 2017. “Can Hatred Speak? On the Linguistic Dimensions of Hate Crime”. Linguistik online 82/3: $5-25$. 
Saunders, Kevin. 2011. Degradation. What the History of Obscenity Tells Us about Hate Speech. New York, London: New York University Press. https://doi.org/10.18574/nyu/9780814741443.001.0001

Scarry, Elaine. 1985. The Body in Pain. The Making and Unmaking of the World. New York, Oxford: Oxford University Press.

Sheftel, Anna. 2013. “I Don't Fancy History Very Much'. Reflections on Interviewee Recruitment and Refusal in Bosnia-Herzegovina”. In Oral History Off the Record. Toward an Ethnography of Practice. Anna Sheftel and Stacey Zembrzycki, eds. New York: Palgrave Macmillan, 255-271. https://doi.org/10.1057/9781137339652_15

Svendsen, Lars. 2008. A Philosophy of Fear. London: Reaktion books.

Waldron, Jeremy. 2012. The Harm in Hate Speech. Cambridge, London: Harvard University Press. https://doi. org/10.4159/harvard.9780674065086

Wetherell, Margaret. 2013. "Feeling Rules, Atmospheres and Affective Practice. Some Reflections on the Analysis of Emotional Episodes". In Privilege, Agency and Affect. Understanding the Production and Effects of Action. Claire Maxwell and Peter Aggleton, eds. New York: Palgrave Macmillan, 221-239. https://doi. org/10.1057/9781137292636_13

Winter, Jay. 2010. “Thinking about Silence”. In Shadows of War. A Social History of Silence in the Twentieth Century. Efrat Ben-Ze'ev, Ruth Ginio and Jay Winter, eds. Cambridge: Cambridge University Press, 3-31. https://doi. org/10.1017/CBO9780511676178.002

Zerubavel, Eviatar. 2006. The Elephant in the Room. Silence and Denial in Everyday Life. Oxford, New York: Oxford University Press. https://doi.org/10.1093/acprof:oso/9780195187175.001.0001

Zerubavel, Eviatar. 2010. “The Social Sound of Silence. Toward a Sociology of Denial”. In Shadows of War. A Social History of Silence in the Twentieth Century. Efrat Ben-Ze'ev, Ruth Ginio and Jay Winter, eds. Cambridge: Cambridge University Press, 32-44. https://doi.org/10.1017/CBO9780511676178.003

\section{Ubojite šutnje? Mržnja, strah i njihove šutnje}

Na primjeru političkog diskursa u Hrvatskoj koji eksplicitnim i implicitnim govorom isključivanja, a često i mržnje proizvodi strah te istraživanja osobnog pripovijedanja straha i tjeskobe marginaliziranih skupina autorica želi ponuditi odgovor na tri temeljna istraživačka pitanja. Prvo, kako se mržnja narativno oblikuje, podjednako u javnom diskursu i osobnim pripovijestima? Drugo, kako jezik mržnje utječe na one koji su označeni kao objekti mržnje? Treće, može li i do koje mjere subjekt anksioznosti/straha (koji je eksplicitni objekt mržnje) pripovijedati svoj doživljaj i emocionalni odgovor na mržnju? Autorica se zanima za mjesta u kojima mržnja (koja je i sama obilježena šutnjom) proizvodi strah i šutnju, odnosno mjesta na kojima mržnja doprinosi potkopavanju potrebe subjekta za intersubjektivnošću i proizvodi duboki osjećaj izolacije i bivanja u šutnji, ali katkada i artikulirani otpor.

Ključne riječi: jezik mržnje, govor mržnje, strah, šutnja, empatija, trač, osobna pripovijest, teorija zavjere, afektivna atmosfera, afektivne politike 